\title{
氧化石墨烯和双酚A对斑马鱼早期发育氧化损伤的 联合效应
}

\author{
杨晶, 陈朋宇, 钟文玨, 祝凌燕* \\ 南开大学环境科学与工程学院, 环境污染过程与基准教育部重点实验室, 天津城市生态环境修复与污染防治重点实验室, 天津 300350 \\ *联系人, E-mail: zhuly@nankai.edu.cn
}

2019-04-18 收稿, 2019-05-23 修回, 2019-05-29 接受, 2019-07-17 网络版发表

国家自然科学基金(21737003)和国家重大水专项(2017ZX070301002)资助

\begin{abstract}
摘要 探讨了氧化石墨烯(graphene oxide, GO) 和双酚A(bisphenol A, BPA)复合暴露对斑马鱼机体氧化损伤的联合 毒性效应. 将斑马鱼胚胎分别暴露于 $\mathrm{BPA}(0,50,500 \mu \mathrm{g} / \mathrm{L}), \mathrm{GO}(0,0.1,1 \mathrm{mg} / \mathrm{L}), \mathrm{BPA}+\mathrm{GO}(50 \mu \mathrm{g} / \mathrm{L}+0.1 \mathrm{mg} / \mathrm{L}, 500 \mu \mathrm{g} / \mathrm{L}$ $+0.1 \mathrm{mg} / \mathrm{L}$ 和 $50 \mu \mathrm{g} / \mathrm{L}+1 \mathrm{mg} / \mathrm{L}, 500 \mu \mathrm{g} / \mathrm{L}+1 \mathrm{mg} / \mathrm{L}$ ) 溶液 $7 \mathrm{~d}$ 后, 测定超氧化物歧化酶(superoxide dismutase, SOD)、丙二 醛(malondialdehyde, MDA)、谷胱甘肽(glutathione, GSH)、过氧化氢酶(catalase, CAT)及活性氧(reactive oxygen species, ROS)等氧化应激相关指标. 结果表明, BPA单独暴露时对斑马鱼胚胎产生较强的氧化损伤效应, 而 $\mathrm{GO}$ 能 缓解由此产生的各种氧化损伤指标. Bliss独立模型计算判断复合暴露组中 GO和BPA具有拮抗效应，表明本实验条 件下GO可以降低BPA对斑马鱼胚胎的氧化损伤毒性.
\end{abstract}

关键词 双酚 $\mathrm{A}(\mathrm{BPA})$, 氧化石墨烯 $(\mathrm{GO})$, 氧化应激, 联合毒性, Bliss独立模型

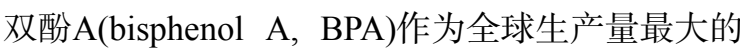
一种化工原料 ${ }^{[1]}$, 当含有BPA的生活用品不完全聚合或 暴露于高温、碱性等环境中时，BPA就会从产品中释 放出来 ${ }^{[2]}$ ，并通过不同的途径排放到环境当中 ${ }^{[3]}$. BPA 在地表水中广泛存在，生产基地附近地表水中BPA的 浓度甚至可高达 $28 \mu \mathrm{g} / \mathrm{L}^{[4]}$. 相关研究发现一些垃圾处 理厂BPA含量可高达 $17.2 \mathrm{mg} / \mathrm{L}$, 平均含量也可达到 269 $\mu \mathrm{g} / \mathrm{L}^{[5]}$, 最终释放到水体环境中 ${ }^{[6]}$, 并对水生生物产生 发育、生殖、免疫等毒性效应 ${ }^{[7]}$. 氧化石墨烯(graphene oxide, GO)作为石墨烯的氧化产物 ${ }^{[8]}$, 由于其独特的物 化性质而被广泛应用于众多行业 ${ }^{[9,10]}$, 并不可避免进人 水体环境中，对水体中共存污染物的环境行为和毒性 效应产生一定的影响. 目前, 环境中GO的实际浓度还 未见诸报道，文献[11,12]中体内和体外 GO毒性实验的 浓度通常设置在 $\mu \mathrm{g} / \mathrm{L} \sim \mathrm{mg} / \mathrm{L}$ 之间. 相关研究表明, GO可
以进人生物体并引起一定的氧化损伤、细胞毒性、基 因毒性和发育毒性 ${ }^{[13 \sim 15]}$.

斑马鱼早期发育阶段对活性氧自由基的伤害非常 敏感, 使其在发育阶段更容易受到外界影响. 氧化应激 是很多疾病的诱因，污染物通过破坏机体氧化与抗氧 化之间的平衡, 诱导机体产生过量活性氧(reactive oxygen species, ROS)并生成大量氧化中间产物, 进而导致 机体发生氧化损伤 ${ }^{[16 ~ 18]}$. 胚胎是斑马鱼的敏感发育阶 段，该时期的不良效应将对后期的生长发育产生重要 影响. 纳米材料如 $\mathrm{GO}$ 和有机污染物如BPA在环境中同 时广泛存在, 而它们对斑马鱼胚胎的氧化损伤机理不

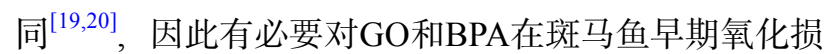
伤的联合效应及机制开展研究. 斑马鱼胚胎在早期发 育时是透明的, 更容易观察和操作, 相对于离体培养细 胞更接近于个体真实环境. 刚孵化出的仔鱼相对于斑

引用格式: 杨晶, 陈朋宇, 钟文玨, 等. 氧化石墨烯和双酚A对斑马鱼早期发育氧化损伤的联合效应. 科学通报, 2019, 64: 2199-2206

Yang J, Chen P Y, Zhong W J, et al. The combined effects of graphene oxide and bisphenol A on oxidative damage in early development of zebrafish (in Chinese). Chin Sci Bull, 2019, 64: 2199-2206, doi: 10.1360/N972019-00340 
马鱼成年个体也更为敏感，因此有很多研究 ${ }^{[21 ~ 23]}$ 都选 择斑马鱼早期发育阶段进行暴露.

本文选取斑马鱼早期阶段进行研究, 分别暴露在 GO, BPA和GO+BPA的分散液中, 研究不同暴露组中 斑马鱼早期氧化损伤相关酶活性变化情况，探讨GO对 BPA对斑马鱼早期阶段引起氧化损伤的影响与机制, 对评估真实环境中二者的环境风险提供一定的科学 依据.

\section{1 材料与方法}

（i ）实验材料. BPA(纯度 $>99.5 \%$ )购自德国Ehrenstorfer $\mathrm{GmbH}$ 公司, 助溶剂二甲基亚砜(DMSO, 色谱纯) 购自美国Sigma Chemical公司. GO纳米片(纯度>99\%) 购于南京先丰纳米科技有限公司. 成年斑马鱼(Danio rerio) 购于天津花鸟鱼虫市场. 斑马鱼饲养在恒温水箱, 温度控制为 $(28 \pm 1)^{\circ} \mathrm{C}, 14 \mathrm{~h} / 10 \mathrm{~h}$ 明暗交替光照, 饲养2周 左右开始收集斑马鱼鱼卵. 饲养水中加人胚胎培养液 $\left(294 \mathrm{mg} / \mathrm{L} \mathrm{CaCl}{ }_{2} \cdot 2 \mathrm{H}_{2} \mathrm{O}, 123 \mathrm{mg} / \mathrm{L} \quad \mathrm{MgSO}_{4} \cdot 7 \mathrm{H}_{2} \mathrm{O}, 63.0\right.$ $\mathrm{mg} / \mathrm{L} \mathrm{NaHCO}$ 和 $5.5 \mathrm{mg} / \mathrm{L} \mathrm{KCl}$ ), 保持 $\mathrm{pH} 7.0$ 左右, 每日 喂食2次. 成鱼在光刺激下追尾、受精. 受精后立即收 集胚胎, 并用培养液冲掉粪便, 剔除未受精的肧胎. 将 肧胎转移到96孔板中, 待发育 6 h(hours post-fertilization, hpf)后在体视显微镜下(Olympus, SZX16, 日本)挑 选出健康的胚胎, 用于后续实验.

(ii) GO和BPA溶液的制备及GO表征. GO用MilliQ水作为溶剂, 超声 $4 \mathrm{~h}$, 配制成 $100 \mathrm{mg} / \mathrm{L} \mathrm{GO}$ 的母液, 避 光存放在 $4.0^{\circ} \mathrm{C}$ 冰箱. 本实验 $\mathrm{GO}$ 暴露浓度设置为 0.1 和 $1 \mathrm{mg} / \mathrm{L}$ (分别标记为 $0.1 \mathrm{G}$ 和 $1 \mathrm{G}$ ). 采用透射电子显微镜 (Transmission electron microscope, TEM, Hitachi HT7700, 日本)观察GO的形貌; 可见光-紫外分光光度 计(Purkinje General T90, 中国)、傅里叶转化红外光谱 仪(FT-IR, Bruker Tensor 27, 德国)表征GO结构特征; 粒 径-Zeta电势分析仪(ZETAPALS/BI-200SM, Brookhaven, 美国)测定GO的动力学直径和Zeta电势. BPA用 DMSO作为助溶剂配置成 $50 \mathrm{~g} / \mathrm{L}$ 的母液, 再用Milli-Q水 稀释至所需浓度, 均避光储存. BPA暴露浓度设定为 50 和 $500 \mu \mathrm{g} / \mathrm{L}$ (标记为 $50 \mathrm{~B}$ 和 $500 \mathrm{~B}$ ), 其中DMSO浓度均为 $0.01 \%$ (体积比), 并且设置 $0.01 \% \mathrm{DMSO}$ (体积比)为对 照组(SC).

(iii) 常规发育指标. 统计 $168 \mathrm{hpf}$ 的孵化率、存活 率及畸形率, 并在4倍显微镜(Olympus X71, 日本)下观 察拍照记录其生长发育情况. 计算方法如下:
孵化率 $=\frac{\text { 餒化数 }}{\text { 总数 }}$,

存活率 $=\frac{\text { 存活数 }}{\text { 总数 }}$,

畸形率 $=\frac{\text { 畸形数 }}{\text { 总数 }}$.

(iv) 生化指标测定. 每个暴露组取 60 条仔鱼, 用去 离子水清洗 2 次, 加入 $3 \mathrm{~mL}$ 预冷的 $0.1 \mathrm{~mol} / \mathrm{L}$ PBS稀释液 ( $\mathrm{pH}$ 7.3), 每组3个平行. 采用超声破碎仪进行匀浆, 直至 组织混合物匀质化, 于 $4^{\circ} \mathrm{C}, 5000 \mathrm{~g}$ 下离心 $15 \mathrm{~min}$. 将 $3 \mathrm{~mL}$ 上清液分别装在 3 个 $1 \mathrm{~mL}$ 离心管中, 于 $-80^{\circ} \mathrm{C}$ 保存. 超氧化物歧化酶(SOD)、丙二醛(MDA)、谷胱甘肽 $(\mathrm{GSH})$ 、过氧化氢酶(CAT)的含量均采用ELISA试剂盒 (哈灵科技有限公司)测定, 参照供应商提供的说明书进 行相关操作. 参照文献[24]方法, 用考马斯亮蓝法测定 总蛋白含量.

（V）ROS测定. 参照文献[25]方法, 当胚胎发育至 $168 \mathrm{hpf}$ 时, 用培养液冲洗数次, 用含 $10 \mu \mathrm{mol} / \mathrm{L} 2,7-二$ 氯苂光素二乙酸盐(2,7-dichlorodihydrofluorescein diacetate, DCFH-HA)胚胎培养液避光孵育, 然后再用培养 液将其冲洗干净. DCFH-HA是非标记性氧化敏感苂光 探针, 自身不会发苂光, 但可自由通过细胞膜. 通过细 胞膜后, DCFH-HA被细胞内酯酶分解成为不能通过细 胞膜的DCFH，使得探针被装载到细胞中. 细胞内 ROS 将DCFH氧化成能发苂光的DCF，苂光的强弱可反映细 胞内ROS浓度. 用 $0.016 \mathrm{~mol} / \mathrm{L}$ 三卡因麻醉胚胎后, 在倒 置苂光显微镜(Olympus X71, 日本)下观察斑马鱼体内 苂光产生的情况，激发波长和发射波长分别为 485 和 $535 \mathrm{~nm}$. 及时拍照记录后用Image-J软件提取相关信息 并确定其荧光强度, 每组设 3 个平行.

(vi) 数据统计分析. 用SPSS 8.0软件进行统计学分 析, 多组间的比较使用方差齐性检验和单因素方差分 析(one-way ANOVA). 对于组间两两比较, 使用LSD检 验, 以 $P<0.05$ 表示差异显著. 采用Pearson相关性分析研 究ROS和MDA之间的相关性. 采用Bliss独立模型对 GO 和BPA的相互作用进行定量分析. 实验结果均以“平均 值土标准误差”即 $(m e a n \pm \mathrm{SD})$ 表示:

$$
\begin{aligned}
& P_{\mathrm{B}}=\frac{\mathrm{BPA}-\text { Control }}{\text { Control }} \times 100 \%, \\
& P_{\mathrm{G}}=\frac{\mid \mathrm{GO}-\text { Control } \mid}{\text { Control }} \times 100 \%, \\
& \mathrm{PE}=P_{\mathrm{B}}+P_{\mathrm{G}}-P_{\mathrm{B}} P_{\mathrm{G}},
\end{aligned}
$$


式中, $P_{\mathrm{B}}$ 和 $P_{\mathrm{G}}$ 分别表示 $\mathrm{BPA}$ 和 $\mathrm{GO}$ 单独暴露下的计算值, PE(predicted effects)表示复合暴露组的预测值. PE大于 $\mathrm{OE}$ (observed effects, 复合暴露组的实测值), 为拮抗作 用(antagonistic，ANT); PE小于 $\mathrm{OE}$ ，为协同作用(synergistic, SYN); PE等于 $O E$, 为相加作用 (additive, ADD).

\section{2 结果与讨论}

\subsection{GO纳米材料的表征}

由紫外光谱可以看出 $\mathrm{GO}$ 水溶液在 $230 \mathrm{~nm}$ 处具有 一个典型特征峰, 它对应的是 $\mathrm{GO}$ 结构中苯环 $\mathrm{C}=\mathrm{C}$ 的 $\pi-\pi$ 跃迁 ${ }^{[26]}$. GO 在 $3340 ， \sim 1720 ， \sim 1620 ， \sim 1400$ 及 $\sim 1070 \mathrm{~cm}^{-1}$ 位置均出现了明显的特征峰, 说明 $\mathrm{GO}$ 纳米 片结构中含有 $-\mathrm{OH},-\mathrm{COOH}, \mathrm{C}=\mathrm{C}, \mathrm{C}-\mathrm{OH}$ 和 $\mathrm{C}-\mathrm{O}-\mathrm{C}$ 等 基团 ${ }^{[27]}$. Zeta电势可指示 $\mathrm{GO}$ 在溶液中的稳定性, 当其绝 对值大于 $30.0 \mathrm{mV}$ 时相对比较稳定 ${ }^{[28]}$. GO在去离子水 溶液的 Zeta 电势为 $(-32.7 \pm 2.63) \mathrm{mV}$, 表明其在去离子 水里具有较好的分散性. 当 $\mathrm{GO}$ 分散在胚胎培养液中时, 由于培养液中阳离子的静电吸附和压缩双电层作用, GO的Zeta电势上升为 $(-14.4 \pm 1.91) \mathrm{mV}$, 说明 $\mathrm{GO}$ 的稳定 性有所下降. 但是溶液中并未观察到明显的沉降絮凝 现象, 说明该培养液满足本研究静态实验的要求. GO 在去离子水和培养液中的水合粒径分别为 $(232 \pm 14.3)$ 和(725 \pm 24.7$) \mathrm{nm}$ ，同样说明培养液中 GO因团聚形成了 大颗粒的团聚体. 图1中TEM图显示 GO在水溶液中为 半透明的二维片层结构, 而在胚胎培养液中则明显变 厚, 进一步说明 $\mathrm{GO}$ 在培养液中有一定程度的团聚.

\section{2 斑马鱼胚胎的死亡、孵化与畸形}

孵化是鱼类生命过程中的一个重要阶段，在相应 的发育阶段鱼卵脱膜孵化是幼鱼存活、受食及进一步 发育的基础. 玟马鱼胚胎孵化 $168 \mathrm{~h}$ 后, 所有暴露组的孵 化率和存活率均 $>95.5 \%$ ，说明实验设计的暴露浓度均 不会对斑马鱼产生明显的急性毒性. 单独 0.1 和 $1 \mathrm{mg} / \mathrm{L}$ 的 $\mathrm{GO}$ 暴露时, 胚胎的孵化率与对照组无显著性差异, 与Chen等人 ${ }^{[28]}$ 的研究结果类似. $500 \mu \mathrm{g} / \mathrm{L}$ 的BPA单独 暴露时，斑马鱼在54 hpf的孵化率 $(74.3 \% \pm 2.41 \%)$ 明显 高于空白组 $(59.6 \% \pm 3.37 \%)$ ，说明中低浓度BPA能促使 肧胎孵化提前 ${ }^{[29]}$. GO 和BPA单独暴露均可以造成斑马 鱼仔鱼畸形(图2). 然而, $500 \mathrm{~B}+1 \mathrm{G}$ 的复合暴露组的畸形 率 $(5.80 \% \pm 2.64 \%$ ) 相对于 $500 \mathrm{~B}$ 单独暴露组 $(13.4 \%$ $\pm 3.33 \%)$ 显著降低 $(P<0.05)$ ． 50B和500B单独暴露组畸

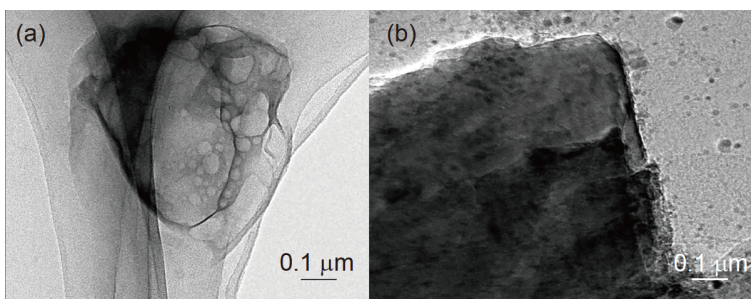

图 1 GO的TEM表征图. (a) 去离子水; (b) 胚胎培养液

Figure 1 TEM images of GO. (a) In deionized water; (b) in embryo culture medium

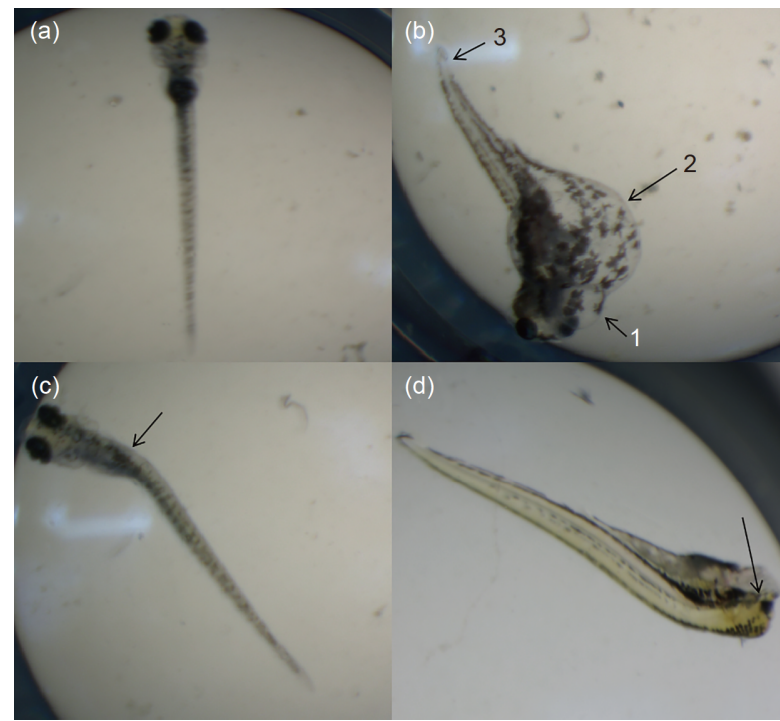

图 2 (网络版彩色)早期斑马鱼畸形图. (a) 正常发育对照组; (b) 1, 心包囊水肿; 2 , 卵黄囊水肿; 3 , 尾畸; (c) 背畸; (d) 没有眼睛

Figure 2 (Color online) Malformations of early zebrafish. (a) Control group; (b) 1, pericardial edema; 2, yolk sac edema; 3 , tail deformity; (c) spinal curvature; (d) no eyes

形率分别为 $(9.60 \% \pm 2.23 \%)$ 和 $(13.4 \% \pm 3.33 \%)$ ，均高于 $0.1 \mathrm{G}(3.30 \% \pm 3.25 \%)$ 和 $1 \mathrm{G}(5.20 \% \pm 3.21 \%)$ 单一暴露组. 这些结果说明本实验条件下BPA对斑马鱼早期发育畸 形影响要强于 $\mathrm{GO}$, 当二者共同作用时, GO在一定程度 上缓解了由BPA主导引起的孵化率提前，畸形率也有 一定程度的降低.

\section{3 单独和复合暴露对活性氧生成的影响}

ROS是广泛存在于生物体内的一种活性物质，线 粒体是大多数细胞产生ROS的主要来源. 通常细胞内 ROS 浓度可以在抗氧化系统调节下保持在正常的生理 水平. 研究报道GO对生物体的主要毒性机制之一是通 过诱导生物体产生活性氧，导致生物体内氧化胁迫损 伤 ${ }^{[28]}$. 图3显示培养溶液中较大的 GO团聚体附着在肧 


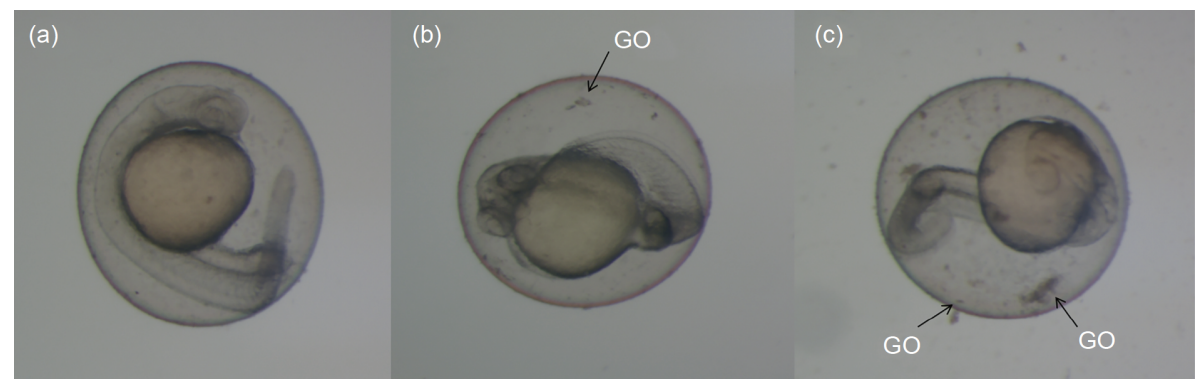

图 3 不同浓度GO对斑马鱼胚胎线膜包覆图. (a) $0 \mathrm{mg} / \mathrm{L}$; (b) $0.1 \mathrm{mg} / \mathrm{L}$; (c) $1 \mathrm{mg} / \mathrm{L}$

Figure 3 Chorionic coating of zebrafish embryos at different concentrations of GO. (a) $0 \mathrm{mg} / \mathrm{L}$; (b) $0.1 \mathrm{mg} / \mathrm{L}$; (c) $1 \mathrm{mg} / \mathrm{L}$

胎线膜表面, 该现象随着 $\mathrm{GO}$ 浓度的升高逐渐明显. $\mathrm{GO}$ 可以附着在胚胎线毛膜表面，阻碍胚胎体内外气体交 换，容易导致胚胎内部环境低氧. 因此在较高浓度 $\mathrm{GO}$ $(1 \mathrm{mg} / \mathrm{L})$ 存在时, 斑马鱼胚胎内产生ROS并引发氧化损 伤(图4, 5), 这与Chen等人 ${ }^{[28]}$ 之前的研究结果一致. BPA 也可以造成斑马鱼胚胎氧化损伤(图4,5). 与GO不同的 是, BPA通过胚胎线膜主动吸收进入胚胎内部, 导致机 体产生氧化损伤现象 ${ }^{[29]}$. 在50B和500B的单独暴露组 中, 斑马鱼胚胎内产生的 $R O S$ 要高于 $0.1 \mathrm{G}$ 和 $1.0 \mathrm{G}$ 的单 独暴露组, 而复合暴露组中ROS显著低于BPA单独暴 露，但显著高于 GO单独暴露组. Bliss模型结果说明 BPA和GO之间对ROS的产生存在拮抗作用(表1)，说明 GO降低了 BPA所导致的斑马鱼早期发育的氧化损伤 毒性.

\section{4 单独和复合暴露对生化指标的影响}

生物体受到外界刺激时会生成大量ROS，生物体 依靠改变体内抗氧化酶的活性进行氧化应激，清除 ROS来降低机体氧化损伤 ${ }^{[30]}$. SOD 是抗氧化酶中最开 始起作用的特异性酶，主要在生物体胞质及线粒体中 存在. SOD可以将超氧阴离子 $\left(\mathrm{O}_{2}{ }^{-}\right)$催化氧化为 $\mathrm{O}_{2}$ 和

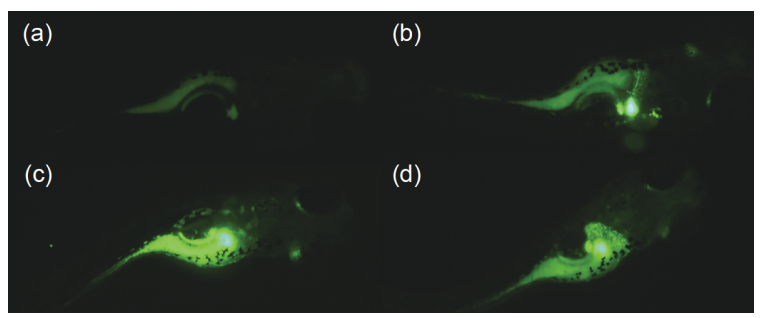

图 4 斑马鱼体内ROS的荧光强度. (a) 空白对照组; (b) GO(1 mg/L); (c) $\mathrm{BPA}(500 \mu \mathrm{g} / \mathrm{L})$; (d) $500 \mu \mathrm{g} / \mathrm{L} \mathrm{BPA}+1 \mathrm{mg} / \mathrm{L} \mathrm{GO}$

Figure 4 The fluorescence intensity of ROS in zebrafish. (a) Control group; (b) GO (1 mg/L); (c) BPA (500 $\mu \mathrm{g} / \mathrm{L})$; (d) $500 \mu \mathrm{g} / \mathrm{L} \mathrm{BPA}+1 \mathrm{mg} / \mathrm{L}$ GO
$\mathrm{H}_{2} \mathrm{O}$, 使ROS维持在生理水平, 保护机体免于损伤 ${ }^{[30]}$. CAT是过氧化物酶体中的含铁血蛋白抗氧化酶，会使 生物体内 $\mathrm{H}_{2} \mathrm{O}_{2}$ 转化为 $\mathrm{O}_{2}$ 和 $\mathrm{H}_{2} \mathrm{O}^{[31]}$, 防止毒性更强 的·OH生成，从而保护生物体免受更大的损伤. ROS过 量会攻击生物膜系统的多不饱和脂肪酸，从而导致脂 质过氧化. MDA是发生不可逆脂质过氧化的产物, $\mathrm{MDA}$ 的变化可反映生物体内脂质过氧化的水平和损 伤程度 ${ }^{[31]}$. GSH 作为生物体内一种重要的非酶抗氧化 剂, 生物提在受到外界刺激后诱导产生GSH, 以有效清 除氧自由基调控氧化应激 ${ }^{[32]}$. 当 GSH 逐渐减少到一定 水平时，生物体将发生中毒效应. 由图6可以看出，在 $\mathrm{BPA}$ 单独暴露时, 斑马鱼仔鱼体内SOD, CAT, GSH均 受到抑制 $(P<0.05)$, 且MDA含量大幅上升 $(P<0.05)$, 这

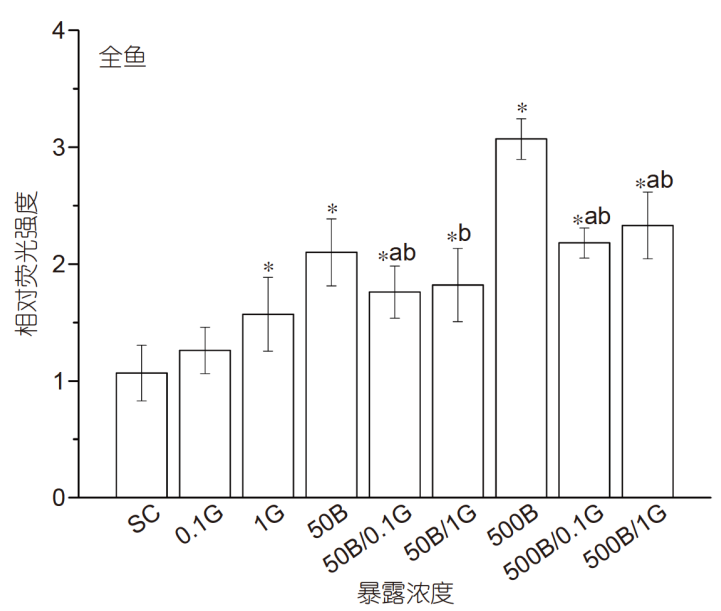

图 5 相对苂光强度. $a$ 代表BPA单独处理组与复合处理组有显著差 异, $P<0.05$. b代表 GO单独处理组与复合处理组有显著差异, $P<0.05$. *代表与对照组有显著差异, $P<0.05$

Figure 5 Relative fluorescence levels in each treatment and control group. a indicates that there is a significant difference between the BPA treatment group alone and the mixed treatment group, $P<0.05$. b indicates that there is a significant difference between the GO treatment group alone and the mixed treatment group, $P<0.05$. $^{*}$ indicates there is a significant difference between treatment and control groups, $P<0.05$ 
表 1 GO和BPA联合毒性的相互作用 ${ }^{\text {a) }}$

Table 1 The interaction between GO and BPA combined toxicity ${ }^{\text {a) }}$

\begin{tabular}{|c|c|c|c|c|c|}
\hline & \multirow{2}{*}{$\begin{array}{c}\mathrm{GO}(\mathrm{mg} / \mathrm{L}) \\
\mathrm{BPA}(\mu \mathrm{g} / \mathrm{L})\end{array}$} & \multicolumn{2}{|c|}{0.1} & \multicolumn{2}{|c|}{1} \\
\hline & & 50 & 500 & 50 & 500 \\
\hline \multirow[t]{3}{*}{ ROS } & $\mathrm{PE}(\%)$ & 107 & 179 & 104 & 146 \\
\hline & $\mathrm{OE}(\%)$ & 76.3 & 118 & 82.5 & 133 \\
\hline & 结论 & ANT & ANT & ANT & ANT \\
\hline \multirow[t]{3}{*}{ SOD } & $\mathrm{PE}(\%)$ & 90.5 & 90.7 & 64.0 & 64.8 \\
\hline & $\mathrm{OE}(\%)$ & 30.7 & 21.5 & 50.6 & 35.3 \\
\hline & 结论 & ANT & ANT & ANT & ANT \\
\hline \multirow[t]{3}{*}{ MDA } & $\mathrm{PE}(\%)$ & 34.1 & 45.7 & 122 & 127 \\
\hline & $\mathrm{OE}(\%)$ & 14.6 & 20.4 & 40.3 & 34.2 \\
\hline & 结论 & ANT & ANT & ANT & ANT \\
\hline \multirow[t]{3}{*}{ CAT } & $\mathrm{PE}(\%)$ & 28.1 & 31.3 & 50.4 & 52.6 \\
\hline & $\mathrm{OE}(\%)$ & 17.5 & 14.6 & 32.1 & 28.9 \\
\hline & 结论 & ANT & ANT & ANT & ANT \\
\hline \multirow[t]{3}{*}{ GSH } & $\mathrm{PE}(\%)$ & 40.2 & 40.4 & 61.6 & 61.7 \\
\hline & $\mathrm{OE}(\%)$ & 22.9 & 20.5 & 42.2 & 38.4 \\
\hline & 结论 & ANT & ANT & ANT & ANT \\
\hline
\end{tabular}

a) PE, 复合暴露预测值; OE, 复合暴露实际值; ANT, 拮抗作用
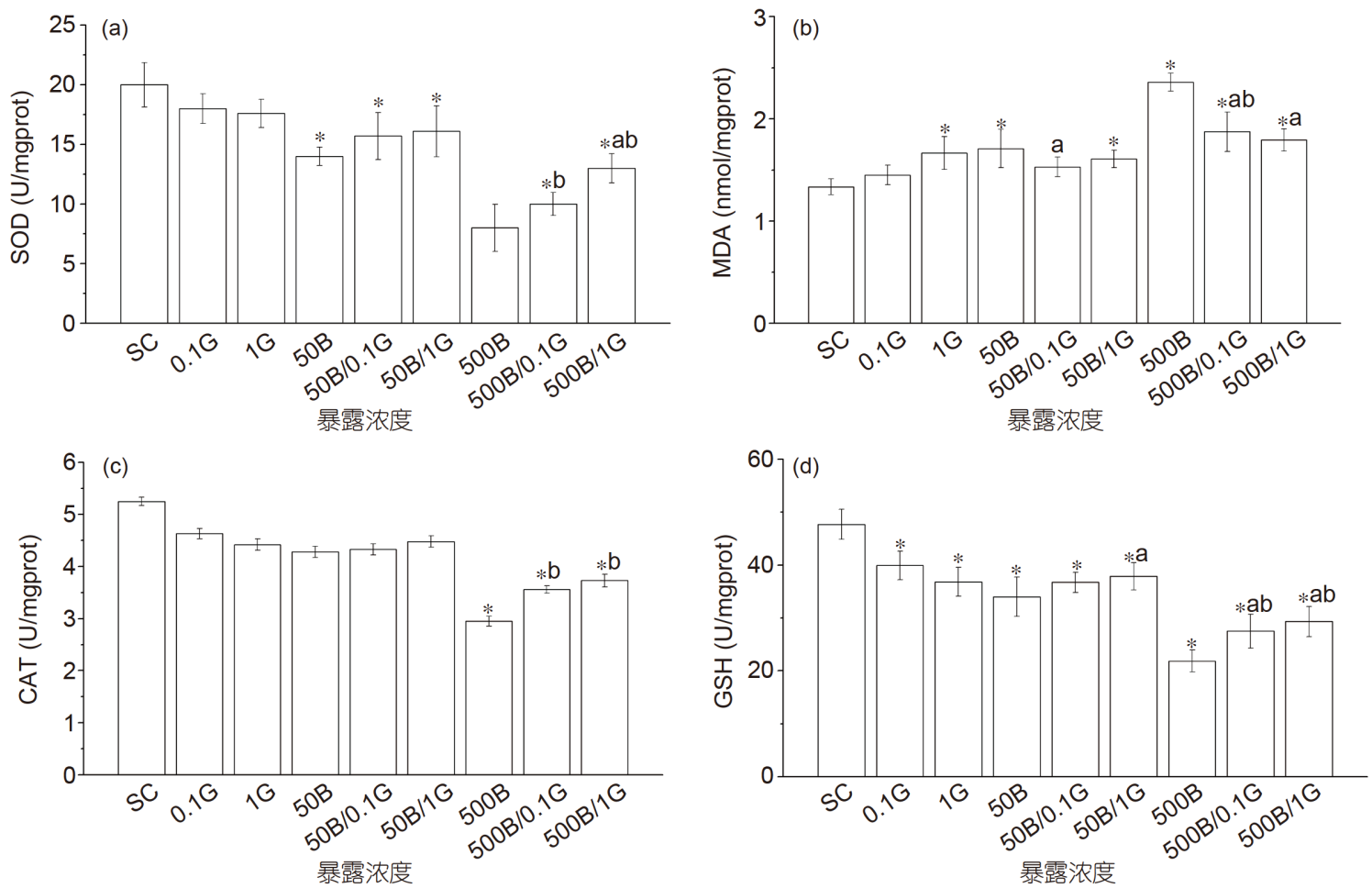

图 $6 \mathrm{GO}(0.1 \mathrm{G}, 1 \mathrm{G})$ 和BPA $(50 \mathrm{~B}, 500 \mathrm{~B})$ 不同暴露处理对斑马鱼 $\mathrm{SOD}(\mathrm{a}), \mathrm{MDA}(\mathrm{b}), \mathrm{CAT}(\mathrm{c})$ 和 $\mathrm{GSH}(\mathrm{d})$ 的影响. a 代表BPA单独处理组与复合处理组 有显著差异, $P<0.05$; b 代表 GO单独处理组与复合处理组有显著差异, $P<0.05$. *代表与对照组有显著差异, $P<0.05$

Figure 6 Effects of different exposure treatments of GO $(0.1 \mathrm{G}, 1 \mathrm{G})$ and BPA $(50 \mathrm{~B}, 500 \mathrm{~B})$ on zebrafish SOD (a), MDA (b), CAT (c) and GSH (d). a indicates that there is a significant difference between the BPA treatment group alone and the mixed treatment group, $P<0.05$. $\mathrm{b}$ indicates that there is a significant difference between the GO treatment group alone and the mixed treatment group, $P<0.05 . *$ indicates there is a significant difference between treatment and control groups, $P<0.05$ 
与 $\mathrm{Wu}$ 等人 ${ }^{[33]}$ 的研究结果一致. 而在 $\mathrm{GO}$ 单独暴露组中, $\mathrm{SOD}, \mathrm{CAT}$ 与对照组相比没有显著性变化, 但GSH受到 抑制 $(P<0.05)$, 且MDA含量上升 $(P<0.05)$. 这与Chen等 ${ }^{[28]}$ 的研究结果略有不同, 可能是由于选用的胚胎培 养液不同, 本实验条件下 $\mathrm{Ca}^{2+}$ 离子浓度相对更高, 使得 $\mathrm{GO}$ 更容易发生团聚. 因此, 尽管 $\mathrm{GO}$ 暴露组中产生了活 性氧，但是本实验条件下SOD与空白对照相比没有显 著性差异. 由图7可见，除了 $0.1 \mathrm{G}$ 组外，其他暴露组的 MDA水平都显著高于空白组 $(P<0.05)$, 且MDA 与胚胎 内 $\mathrm{ROS}$ 水平呈现正相关性 $\left(R^{2}=0.905\right)$, 说明由于暴露引 起的活性氧物质上升是导致机体内脂质过氧化的主要 原因. 与单独 $\mathrm{GO}$ 暴露相比, 复合暴露组与氧化损伤相 关的指标均有所增强; 然而, 与单独BPA暴露相比, 复 合暴露组氧化损伤相关的指标均有所缓解. Bliss模型 结果说明 GO 和BPA对斑马鱼早期氧化酶活性均为拮抗 作用(表1). 这些结果表明，在此实验条件下，BPA单独 暴露对于斑马鱼氧化损伤要强于 $\mathrm{GO}$ 单独暴露组; 而二 者共同暴露时, $\mathrm{GO}$ 能减轻BPA对斑马鱼氧化损伤.

\section{5 复合暴露致毒机理分析}

上述研究结果说明，在斑马鱼早期发育阶段过程 中, GO和BPA对斑马鱼胚胎体内活性氧的产生、氧化 损伤及孵化率等存在拮抗效应. GO不仅会附着在胚胎 线膜或者细胞膜上, 阻止BPA通过胚胎线主动吸收进 人胚胎. 而且GO对BPA具有一定的吸附作用 ${ }^{[34]}$, 可能 降低暴露溶液中自由态BPA的浓度, 也在一定程度上 降低了BPA在胚胎中的富集, 从而缓解了由于BPA主导 造成的氧化损伤. 已有相关研究表明, 多壁碳纳米管 (MCNWs) 可以降低全氟辛烷磺酸(PFOS)对斑马鱼早 期阶段氧化应激作用 ${ }^{[35]}$. 富勒烯(C60)吸附 $17 \alpha$-乙炔基

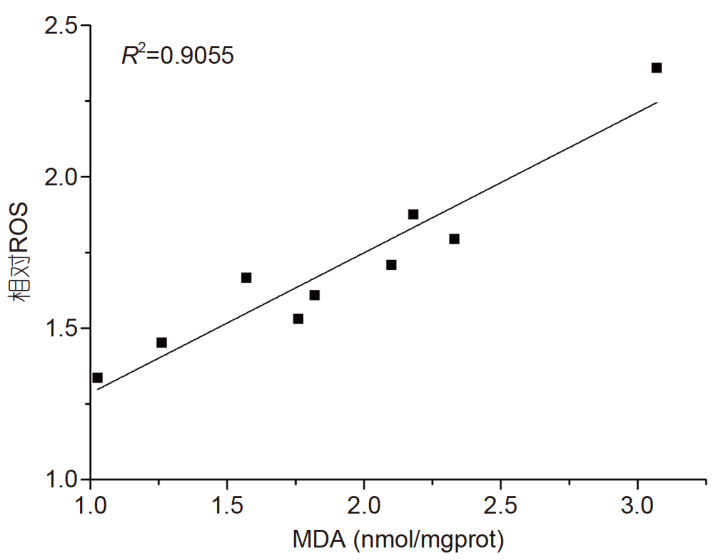

图 7 ROS与MDA之间的相关性

Figure 7 Correlation between ROS and MDA

雌二醇(EE2)后降低了EE2的生物可利用性，缓解了 EE2对斑马鱼的毒性 ${ }^{[36]}$. 这些研究结果表明由于 $\mathrm{GO}$ 与 有机物之间相互作用，在一定程度上都有可能降低有 机污染物对斑马鱼发育早期的毒性.

\section{3 结论}

BPA单独存在时, 会诱导斑马鱼胚胎产生活性氧 ROS, 导致机体脂质过氧化、孵化提前等毒害效应. 高 浓度的 $\mathrm{GO}$ 组也会诱导斑马鱼胚胎产生少量活性氧物 质和MDA. 当二者共同作用时, GO和BPA对斑马鱼早 期活性氧的产生及氧化酶活性均产生拮抗效应，表现 为 GO缓解了 $\mathrm{BPA}$ 所导致的氧化损伤效应. 这可能是由 于包覆在线毛膜表面的 GO在一定程度上抑制了 $\mathrm{BPA}$ 的 主动吸收, 同时 $\mathrm{GO}$ 通过吸附降低溶液中自由态BPA, 导 致BPA在斑马鱼胚胎中富集量降低, 从而缓解了由BPA 所主导的氧化损伤效应. 研究结果为科学评估GO纳米 材料的环境行为和环境风险提供理论依据.

\section{参考文献}

1 Huang Y Q, Wong C K C, Zheng J S, et al. Bisphenol A (BPA) in China: A review of sources, environmental levels, and potential human health impacts. Environ Int, 2012, 42: 91-99

2 Le H H, Carlson E M, Chua J P, et al. Bisphenol A is released from polycarbonate drinking bottles and mimics the neurotoxic actions of estrogen in developing cerebellar neurons. Toxicol Lett, 2008, 176: 149-156

3 Calafat A M, Kuklenyik Z, Reidy J A, et al. Urinary concentrations of bisphenol A and 4-nonylphenol in a human reference population. Environ Health Persp, 2005, 113: 391-395

4 Heisterkamp I, Gandrass J, Ruck W. Bioassay-directed chemical analysis utilizing LC-MS: A tool for identifying estrogenic compounds in water samples? Anal Bioanal Chem, 2004, 378: 709-715

5 Flint S, Markle T, Thompson S, et al. Bisphenol A exposure, effects, and policy: A wildlife perspective. J Environ Manage, 2012, 104: 19-34

6 Calafat A M, Ye X, Wong L Y, et al. Exposure of the U.S. Population to bisphenol A and 4-tertiary-octylphenol: 2003-2004. Environ Health Persp, 2008, 116: 39-44

7 Siracusa J S, Yin L, Measel E, et al. Effects of bisphenol A and its analogs on reproductive health: A mini review. Reprod Toxicol, 2018, 79: 96- 
123

8 Shen H, Zhang L, Liu M, et al. Biomedical applications of graphene. Theranostics, 2012, 2: 283-294

9 Novoselov K S, Geim A K, Morozov S V, et al. Electric field effect in atomically thin carbon films. Science, 2004, 306: 666-669

10 Tabish T A, Memon F A, Gomez D E, et al. A facile synthesis of porous graphene for efficient water and wastewater treatment. Sci Rep, 2018, 8: 1817

$11 \mathrm{Hu}$ X, Li D, Gao Y, et al. Knowledge gaps between nanotoxicological research and nanomaterial safety. Environ Int, 2016, 94: 8-23

12 Zhang X L, Zhou Q X, Zou W, et al. Molecular mechanisms of developmental toxicity induced by graphene oxide at predicted environmental concentrations. Environ Sci Technol, 2017, 51: 7861-7871

13 Ouyang S, Hu X, Zhou Q. Envelopment-internalization synergistic effects and metabolic mechanisms of graphene oxide on single-cell Chlorella vulgaris are dependent on the nanomaterial particle size. ACS Appl Mater Interfaces, 2015, 7: 18104-18112

$14 \mathrm{Hu} \mathrm{X}, \mathrm{Lu} \mathrm{K}, \mathrm{Mu} \mathrm{L}$, et al. Interactions between graphene oxide and plant cells: Regulation of cell morphology, uptake, organelle damage, oxidative effects and metabolic disorders. Carbon, 2014, 80: 665-676

15 Ema M, Hougaard K S, Kishimoto A, et al. Reproductive and developmental toxicity of carbon-based nanomaterials: A literature review. Nanotoxicology, 2016, 10: 391-412

16 Dong M, Zhu L, Zhu S, et al. Toxic effects of 1-decyl-3-methylimidazolium bromide ionic liquid on the antioxidant enzyme system and DNA in zebrafish (Danio rerio) livers. Chemosphere, 2013, 91: 1107-1112

17 Valavanidis A, Vlahogianni T, Dassenakis M, et al. Molecular biomarkers of oxidative stress in aquatic organisms in relation to toxic environmental pollutants. Ecotoxicol Environ Saf, 2006, 64: 178-189

18 Parng C. In vivo zebrafish assays for toxicity testing. Curr Opin Drug Discov Devel, 2005, 8: 100-106

19 Liao K H, Lin Y S, Macosko C W, et al. Cytotoxicity of graphene oxide and graphene in human erythrocytes and skin fibroblasts. ACS Appl Mater Interfaces, 2011, 3: 2607-2615

20 Qiu W, Shen Y, Pan C, et al. The potential immune modulatory effect of chronic bisphenol A exposure on gene regulation in male medaka (Oryzias latipes) liver. Ecotoxicol Environ Saf, 2016, 130: 146-154

21 Ardouin O, Legouis R, Fasano L, et al. Characterization of the two zebrafish orthologues of the KAL-1 gene underlying X chromosome-linked Kallmann syndrome. Mech Dev, 2000, 90: 89-94

22 Bar-Ilan $\mathrm{O}$, Chuang $\mathrm{C} \mathrm{C}$, Schwahn D J, et al. $\mathrm{TiO}_{2}$ nanoparticle exposure and illumination during Zebrafish development: Mortality at parts per billion concentrations. Environ Sci Technol, 2013, 47: 4726-4733

23 Mcgee S P, Cooper E M, Stapleton H M, et al. Early zebrafish embryogenesis is susceptible to developmental TDCPP exposure. Environ Health Persp, 2012, 120: 1585-1591

24 Chen P Y, Wang Q, Zhu L Y, et al. Antagonistic estrogenic effects displayed by bisphenol AF and perfluorooctanoic acid on zebrafish (Danio rerio) at an early developmental stage. Environ Sci Tech Lett, 2018, 5: 655-661

25 Cheng J P, Flahaut E, Cheng S H. Effect of carbon nanotubes on developing zebrafish (Danio rerio) embryos. Environ Toxicol Chem, 2007, 26: $708-716$

26 Du J, Hu X, Zhou Q. Graphene oxide regulates the bacterial community and exhibits property changes in soil. RSC Adv, 2015, 5: 27009-27017

27 Sun B B, Zhang Y Q, Zhu L Y, et al. Concentration dependent effects of bovine serum albumin on graphene oxide colloidal stability in aquatic environment. Environ Sci Technol, 2018, 52: 7212-7219

28 Chen Y M, Hu X G, Sun J, et al. Specific nanotoxicity of graphene oxide during zebrafish embryogenesis. Nanotoxicology, 2016, 10: 42-52

29 Qiu W, Zhao Y, Yang M, et al. Actions of bisphenol A and bisphenol S on the reproductive neuroendocrine system during early development in zebrafish. Endocrinology, 2016, 157: 636-647

30 Yu L, Lam J C W, Guo Y, et al. Parental transfer of polybrominated diphenyl ethers (PBDEs) and thyroid endocrine disruption in zebrafish. Environ Sci Technol, 2011, 45: 10652-10659

31 Morel Y, Barouki R. Repression of gene expression by oxidative stress. Biochem J, 1999, 342: 481-496

32 Jin Y X, Zhang X X, Shu L J, et al. Oxidative stress response and gene expression with atrazine exposure in adult female zebrafish (Danio rerio). Chemosphere, 2010, 78: 846-852

$33 \mathrm{Wu} \mathrm{M}, \mathrm{Xu} \mathrm{H}$, Shen Y, et al. Oxidative stress in zebrafish embryos induced by short-term exposure to bisphenol A, nonylphenol, and their mixture. Environ Toxicol Chem, 2011, 30: 2335-2341

34 Bele S, Samanidou V, Deliyanni E. Effect of the reduction degree of graphene oxide on the adsorption of Bisphenol A. Chem Eng Res Des, 2016, 109: $573-585$

35 Wang S T, Zhuang C L, Du J. The presence of MWCNTs reduces developmental toxicity of PFOS in early life stage of zebrafish. Environ Pollut, 2017, 222: 201-209

36 Park J W, Henry T B, Menn F M, et al. No bioavailability of $17 \alpha$-ethinylestradiol when associated with $n \mathrm{C}_{60}$ aggregates during dietary exposure in adult male zebrafish (Danio rerio). Chemosphere, 2010, 81: 1227-1232 


\title{
The combined effects of graphene oxide and bisphenol A on oxidative damage in early development of zebrafish
}

\author{
Jing Yang, Pengyu Chen, Wenjue Zhong \& Lingyan Zhu* \\ Key Laboratory of Pollution Processes and Environmental Criteria of Ministry of Education, Tianjin Key Laboratory of Environmental Remediation and \\ Pollution Control, College of Environmental Science and Engineering, Nankai University, Tianjin 300350, China \\ * Corresponding author, E-mail: zhuly@nankai.edu.cn
}

Bisphenol A (BPA) is widely present in natural surface water, and was found to be at the high level of $\mu \mathrm{g} / \mathrm{L}$ in the surface water around a BPA manufacturing plant. Mass production and application make BPA ubiquitous in the environment, biota and humans. As a two-dimensional carbon based nanomaterial, graphene oxide (GO) is used in many fields, and there is a great potential for GO to discharge to aquatic environment via various pathways. Thus GO has the potential to interact with organic pollutants, such as BPA, copresent in water system. GO could adsorb organic pollutants in water, and adhere on the surface of organisms, displaying different effects on the behaviors and toxicities of organic pollutants in organisms at different developmental stages. But the intrinsic mechanisms for the different effects remain unclear. To fill this gap, zebrafish (Danio rerio) was selected as a vertebrate model to investigate the toxicities of a variety of pollutants and nanomaterials in this study. Embryogenesis is an important growth phase in the zebrafish life cycle. Pollutants can induce excessive reactive oxygen species (ROS) and generate a large number of oxidative intermediate products by destroying the balance between oxidation and antioxidation, thus causing oxidative damage. Superoxide dismutase (SOD) can catalyze the oxidation of superoxide anion $\left(\mathrm{O}_{2}^{-}\right)$to $\mathrm{O}_{2}$ and $\mathrm{H}_{2} \mathrm{O}$, in an attempt to maintain $\mathrm{ROS}$ at a physiological level and protect the body from damage. Catalase (CAT) exists primarily within peroxisomes and removes the $\mathrm{H}_{2} \mathrm{O}_{2}$ generated by the longchain fatty acid $\beta$-oxidation pathway. Excessive ROS can attack the polyunsaturated fatty acids in the biomembrane system, resulting in lipid peroxidation. Malondialdehyde (MDA) is the product of irreversible lipid peroxidation, and the change of MDA can reflect the level and damage degree of lipid peroxidation in organisms. Glutathione (GSH), as an important non-enzymatic antioxidant in organism, can be induced and effectively scavenged by external stimulation to regulate oxidative stress. Toxic effects occur in organisms when GSH is gradually reduced. This study focused on the joint effects of GO and BPA on the oxidative responses in zebrafish at early development stage. Zebrafish embryos were individually exposed to BPA $(0,50,500 \mu \mathrm{g} / \mathrm{L}), \mathrm{GO}(0,0.1,1 \mathrm{mg} / \mathrm{L}), \mathrm{BPA}+\mathrm{GO}(50 \mu \mathrm{g} / \mathrm{L}+0.1 \mathrm{mg} / \mathrm{L}, 500 \mu \mathrm{g} / \mathrm{L}+0.1 \mathrm{mg} / \mathrm{L}$, and $50 \mu \mathrm{g} / \mathrm{L}+1 \mathrm{mg} / \mathrm{L}, 500 \mu \mathrm{g} / \mathrm{L}+1 \mathrm{mg} / \mathrm{L}$ ) solutions for $7 \mathrm{~d}$. The levels of SOD, MDA, GSH, CAT, and ROS in the exposed zebrafish larvae were determined. The results indicated that BPA displayed strong oxidative damage effects on zebrafish larvae. However, the presence of GO distinctly alleviated the various indicators of oxidative damages caused by BPA. Based on analyses using the Bliss independence model, GO and BPA exhibited antagonistic effects on the oxidative damage of zebrafish in the early development stage, which indicated that GO could reduce the oxidative damage toxicities of BPA on zebrafish embryos under the experimental conditions. These could be due to the formation of a GO layer on the zebrafish embryos, which depressed the absorption of BPA by zebrafish, leading to reduced BPA accumulation in zebrafish in early developmental stage.

bisphenol A (BPA), graphene oxide (GO), oxidative damages, joint effects, Bliss independence model doi: 10.1360/N972019-00340 